\title{
Interest in Entrepreneurship: The Role of Entrepreneurial Motivation as a Mediating Variable to Student of ITB ASIA Malang
}

\section{Ummi Saadah ${ }^{1}$}

Cipto Wardoyo ${ }^{2}$

\section{Madziatul Churiyah ${ }^{3}$}

1Program Study of Business and Management Education, Faculty of Economics and Business, Universitas Negeri Malang, Indonesia

2Department of Management, Faculty of Economics and Business, Universitas Negeri Malang, Indonesia

${ }^{3}$ Department of Economic Development, Faculty of Economics and Business, Universitas Negeri Malang, Indonesia

\begin{tabular}{ll}
\hline ARTICLE INFO & ABSTRACT \\
\hline ISSN: 2723-1097 & $\begin{array}{l}\text { This article aims to find out: (1) the effect of entrepreneurship education and gender } \\
\text { on entrepreneurial motivation; (2) the effect of entrepreneurial motivation, } \\
\text { entrepreneurshipeducation and gender on interest in entrepreneurship; and (3) the } \\
\text { influence of entrepreneurship education and gender on interest in entrepreneurship } \\
\text { through entrepreneurial motivation. The research design implemented in this } \\
\text { research is quantitative approach using proportional random sampling, of which } \\
\text { data is collected using a questionnaire and the findings were analyzed by path. The } \\
\text { entrepreneurship } \\
\text { education; gender; } \\
\text { entrepreneurial } \\
\text { motivation; interest in } \\
\text { entrepreneurship. }\end{array} \quad \begin{array}{l}\text { ITB ASIA Malang who has taken Entrepreneurship course in a total of 226 people. } \\
\text { Based on the research findings, it can be concluded as follow. The research findings } \\
\text { indicate that there is a direct effect of entrepreneurship education on gender } \\
\text { through entrepreneurial motivation that mediate the effect of all the variables on } \\
\text { interest in entrepreneurship. Based on the findings, it is discovered that } \\
\text { entrepreneurial knowledge is needed to find out how to prepare business capital } \\
\text { and business documents to promote entrepreneurship, and develop the running } \\
\text { business. Entrepreneurial motivation is needed to build someone with interest in } \\
\text { entrepreneurship. }\end{array}$ \\
\hline
\end{tabular}

\section{Introduction}

Students' lack of interest in entrepreneurship can be seen from the business incubation program and business practice in which students only take the course for the sake of a compulsory subject and to get the grade from the said course, not out of curiosity in learning about entrepreneurship; and the low participation of students in entrepreneurship programs organized by the Faculty of Economics or the PKM-K (Student Entrepreneurship Creativity Program). It is very unfortunate that the said program intended to facilitate students to be creative in entrepreneurship field is not optimally utilized.

Journal of Business and Management Review Vol. 2 No.6 Page 432-444

DOI: $10.47153 /$ jbmr26.1692021

*Corresponding Author

Email address: ummi.saadah.1904158@students.um.ac.id 
Unemployment has become a serious problem in Indonesia and is still difficult to overcome. Head of National Planning and Development Board (Bappenas, 2020), Suharso Monoarfa informed that the number of unemployment in Indonesia rose by 3.7 million people because of COVID-19 pandemic. BPS (Central Bureau of Statistics) recorded that the total of the unemployed as of February 2020 are 6.88 million people. With this addition, the number of the unemployed in Indonesia can reach about 10.58 million people. The government's program to reduce unemployment is still unable to overcome the said problem. This is caused by the enormous number of Indonesian population and still growing, but is not complemented by increasing employment.

Students' interest in entrepreneurship can be enhanced through their knowledge, insight, and competence of entrepreneurship. In building entrepreneurial spirit, there has to be interest and spirit in operating owned business. Interest in entrepreneurship can be seen as a motive to create a new business or as a behavior to boldly take risks to start a new business and a will that can be developed with the presence of motivation (Kurnianti, 2015).

One of the influential factors in the emergence of interest in entrepreneurship is entrepreneurial motivation. Entrepreneurial motivation effects positively and significantly to the interest of entrepreneurship (Solesvik, 2012). Entrepreneurial motivation includes motivation directed to reach entrepreneurial goals, like involvement of introduction and exploitation of business opportunities (Baum et al, 2007). The many ways to manage the student's behavior are enhancing communication and teaching strategy thus the learning and teaching purposes can be achieved effectively and efficiently. Entrepreneurial motivation can be obtained in the effective learning and teaching process. Entrepreneurial motivation is also solidified by demographic factors such as gender, experience, and parent's occupation.

Entrepreneurship education is a stage that people pass, starting from information about entrepreneurship world, giving assets of potential and skills of entrepreneurship, and lastly, giving stimulus for entrepreneurs to start their business (Souitaris, et al, 2007). Linan, et al (2011) stated that entrepreneurship is a process in which entrepreneurs interact with their environment to identify opportunities and finally start a new business. Lestari and Wijaya (2012) stated that entrepreneurship education significantly takes effect on interest in entrepreneurship. The meant entrepreneurship education is a learning process to change students' behavior and mindset on their options in entrepreneurship career. Entrepreneurship education is an effort to internalized entrepreneurial spirit and mentality through educational institutions. Entrepreneurship education is aimed to motivate and shape entrepreneurial mental attitude. Entrepreneurship education effects positively and significantly to the interest in entrepreneur (Hutagalung, et al, 2017). Identification about the role of motivation to increase entrepreneurship success basically shows that entrepreneurial ethos can be stimulated and this is supported by the findings about the role of internal-external factors or pull-and-push factors. 
Guzman and Kacperczyk (2019) stated that gender is a difference between female and male entrepreneur in a different and accumulated stage. Wardhani and Puspitasari (2019) stated that gender helps college students understanding the function of gender and dialectics that rise as social construct attached to someone's sex of which does not form wrong stereotype. Patriana (2007) stated that there is a significant difference in interest in entrepreneurship between men and women, compared to the tendency of women choosing entrepreneurship to achieve their future goals. Another research done by Barlin (2011) found that gender affects the interest in entrepreneurship. The influence of people in students' surrounding environment also takes part in affecting the interest of students in entrepreneurship that is stated by Alma (2013). Gender affects significantly to entrepreneurial motivation (Aidha, 2016). There is a significant difference in interest in entrepreneurship between men and women, in which men tend to choose entrepreneurship to achieve their future goals. Entrepreneurship education variable and interest in entrepreneurship is closely related.

The main problem observed from most students is that it is actually parents and families' wish for the students to become an employee after graduation, not of their own will. Several students explained that their parents viewed the business, most importantly, needs a great deal of initial assent, and the parents also feared that their children would be harmed by the business world.

\section{Literature Review}

\section{Entrepreneurship Education}

Ali (2013) stated that entrepreneurship education is an effort to internalize the entrepreneurial mind through educational institutions and other organizations, i.e. training and coaching organizations. Souitaris, et al, (2007) stated that entrepreneurship education is a stage that a person goes through, starting from information about the entrepreneurship world, providing the provisions of potential and skills in entrepreneurship, and lastly, giving stimulus for entrepreneurs to start their business. Lestari and Wijaya (2012) conducted a research on the influence of entrepreneurship education in the interest in entrepreneurship of college students. The study showed that entrepreneurship education affects significantly to students' interest in entrepreneurship. Farhangmehr, et al (2016) stated that transmission process of knowledge and skills in entrepreneurship for college students help them utilize business opportunities they will face in the future. Based on the experts' arguments, it can be concluded that entrepreneurship education is a systematic effort in the plan of giving knowledge related to the business opportunities that are widely opened and still growing. Various sources obtained by entrepreneurs are related to entrepreneurship education, one of them being universities that include entrepreneurship courses in their learning process.

\section{Gender}


Dayakishi and Yuniardi (2008) stated that sex is a biological and physical difference between men and women, with contrast anatomical difference in the reproduction system of male and female. Sex is a difference between men and women that is viewed from 3 aspects: cognitive, connotative, and affective that shaped behavioral characteristics. Gender is a system or structure in which both men and women are victims of the mentioned system. These gender forms are observed from several indicators: female marginalization, subordination, stereotypical view, violence, and doubled workload. From this research, the hypothesis is that gender does not have a positive and significant effect on entrepreneurial motivation nor interest in entrepreneurship through entrepreneurial motivation in ITB ASIA Malang.

\section{Entrepreneurial Motivation}

Entrepreneurial motivation includes motivation directed to reach entrepreneurial goals, such as involvement of introduction and exploitation of business opportunities (Baum, et al, 2007). Entrepreneurial motivation can grow and develop in starting new business, in which the effort to be confident in their competences is greatly needed to build the business. Growing one's entrepreneurial motivation requires process and learning, but to do entrepreneurship learning, one should have the competence to access information about entrepreneurship opportunities. High motivation must exist in an entrepreneur because motivation will foster a strong mentality to excel in doing a job (Wulandari, 2021). According to Olugbola (2017), indicator of entrepreneurial motivation can be viewed from achievement motive, benefit-gaining motive, the want to be independent, and the sense of interest in entrepreneurship. From this research, the hypothesis is that entrepreneurial motivation does not have a positive and significant effect on the interest in entrepreneurship in ITB ASIA Malang.

\section{Interest in Entrepreneurship}

In Indonesia, a study of interest in entrepreneurship has been done by Indarti and Rostiana (2008). Interest in entrepreneurship is broadly affected by personality characteristics, demographic, and environmental factors. The research is done to understand the interest and driving factors in entrepreneurship of college students in 3 countries. Alma (2013) stated that the measurement of interest in entrepreneurship can be obtained through 25 indicators, i.e. believing in one's self, optimistic, leadership, flexibility, ability to manage money, imagination, ability to plan, patient, assertive, passionate, responsible, realistic, organization, accuracy, composure, risk consideration, physical health, communication with others, freedom, and ability to socialize. According to Nurmaliza, (2018) indicator of interest in entrepreneurship can be observed through the sense of liking entrepreneurship, interest, attention, and involvement. From this research, the hypothesis is that entrepreneurship education does not have a positive and significant effect on interest in entrepreneurship in ITB ASIA Malang. 


\section{Method}

The research design implemented in this research is quantitative approach using descriptive and verificative methods. Students of Faculty of Economics of ITB ASIA Malang who has taken Entrepreneurship course are used as sample with a total population of 226 respondents. The purpose of this study is to understand and to review the connection of entrepreneurship education, gender, interest in entrepreneurship, and entrepreneurial motivation of the students of ITB ASIA Malang. This research design is shown in the picture below (Figure 1).

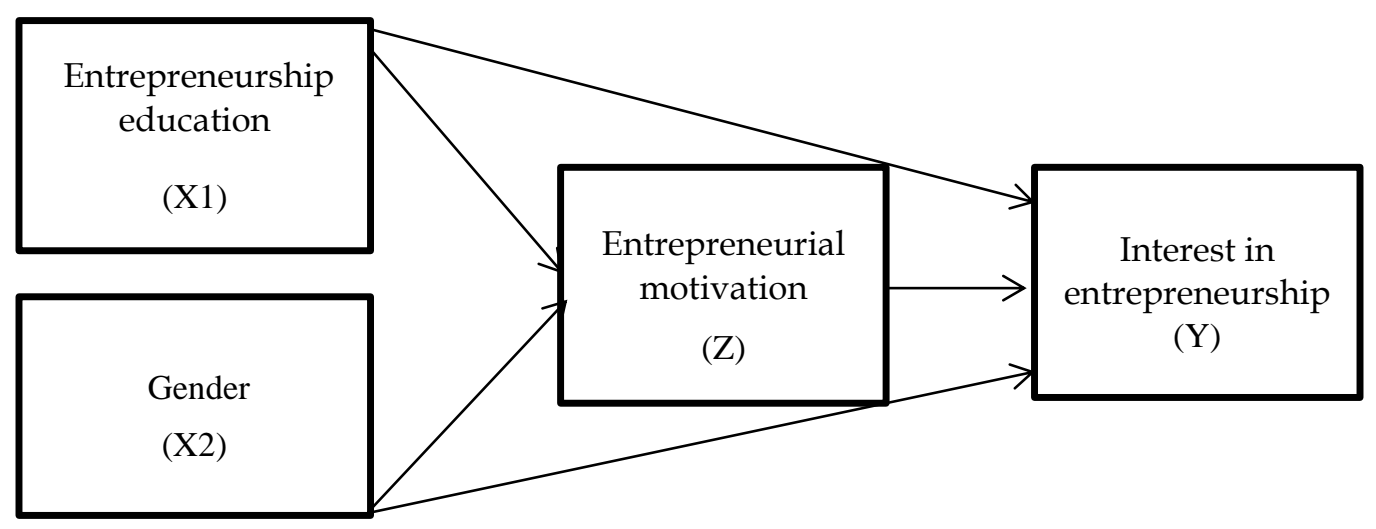

Figure 1. Research Design

\section{Annotation}

$\mathrm{X}_{1} \quad=$ Entrepreneurship education

$\mathrm{X}_{2} \quad$ = Gender

$\mathrm{Z} \quad=$ Entrepreneurial motivation

$\mathrm{Y} \quad=$ Interest in entrepreneurship

$\rightarrow \quad=$ Causal relationship with direct effect from variable $\mathrm{X}$ to $\mathrm{Y}$

\section{Result and Discussion}

In the examination of findings, there are various ways to analyze that need to be completed, such as classic assumption test to further processed using multiple regression analysis. This analysis uses T-test. The discussion of T-test and coefficient of determination (R2) is done in this chapter.

Ghozali (2011) stated that T-test shows the power of the partial effect of independent variable to the dependent variable. Since the researcher tested the relation of two independent variables, T-test is done with the significance level of $5 \%$, thus the value of $\mathrm{t}_{\text {table }}$ of 1.65573 as shown in the appendix. T-test compares results of 
$t_{\text {count }}$ to $t_{\text {table; }}$ if $t_{\text {count }}$ is greater than $t_{\text {table }}, H_{0}$ is rejected and $H_{a}$ is accepted, vice versa. The result of T-test equation I is shown below.

Table 1. Effect of Entrepreneurship Education and Gender to Interest in Entrepreneurship

\begin{tabular}{ccccc}
\hline Independent Variable & $\mathbf{T}_{\text {count }}$ & $\mathbf{t}_{\text {table }}$ & Sig & Note \\
\hline Entrepreneurship education & 6.571 & 1.65573 & 0.000 & $\mathrm{H}_{\mathrm{a}}$ is accepted \\
\hline Gender & 2.945 & 1.65573 & 0.004 & $\mathrm{H}_{\mathrm{a}}$ is accepted
\end{tabular}

Source: Processed by the researcher, 2021.

\section{Effect of Entrepreneurship Education $\left(X_{1}\right)$ to Interest in Entrepreneurship (Y)}

Based on the analysis results, it is discovered that interest in entrepreneurship variable $(\mathrm{Y})$ is explained by entrepreneurship education $\left(\mathrm{X}_{1}\right)$ by 6.571 with the probability magnitude (Sig.) for entrepreneurship education of $0.000<0.05$ and the value of $t_{\text {count }} \geq t_{\text {table }}(6.571>1.65573)$. This means that entrepreneurship education variable $\left(\mathrm{X}_{1}\right)$ affects positively and significantly to the interest in entrepreneurship $(Y)$. Therefore, $\mathrm{H}_{\mathrm{a}}$ is accepted (significant), that implies entrepreneurship education variable $\left(X_{1}\right)$ makes a significant effect on interest in entrepreneurship $(Y)$. It can be interpreted that entrepreneurship education variable affects interest in entrepreneurship.

\section{Effects of Gender $\left(X_{2}\right)$ to Interest in Entrepreneurship $(Y)$}

Based on the analysis results, it is discovered that interest in entrepreneurship variable $(\mathrm{Y})$ is explained by gender variable $\left(\mathrm{X}_{2}\right)$ by 2.945 with the probability magnitude (Sig.) for entrepreneurship education of $0.004<0.05$ and the value of $t_{\text {count }}$ $\geq t_{\text {table }}(2.945>1.65573)$. This means that gender variable $\left(X_{2}\right)$ affects positively and significantly to the interest in entrepreneurship $(Y)$. Therefore, $H_{a}$ is accepted (significant), that implies gender variable (X2) makes a significant effect on interest in entrepreneurship $(Y)$. It can be interpreted that gender variable affects interest in entrepreneurship. Analysis of Table 2 provides results of T-test equation II.

Table 2. Effects of Entrepreneurship Education, Gender, and Interest in Entrepreneur in Entrepreneurial Motivation

\begin{tabular}{lllll}
\hline Independent Variable & $\mathbf{t}_{\text {count }}$ & $\mathbf{t}_{\text {table }}$ & Sig & Note \\
\hline Entrepreneur education & 11.580 & 1.65573 & 0.000 & $\mathrm{H}_{\mathrm{a}}$ is accepted \\
\hline Gender & 1.039 & 1.65573 & 0.301 & $\mathrm{H}_{\mathrm{a}}$ is accepted \\
\hline
\end{tabular}


Interest in entrepreneurship $\quad 8.172 \quad 1.65573 \quad 0.000 \quad \mathrm{H}_{\mathrm{a}}$ is accepted

Source: Processed by the researcher, 2021.

\section{Effects of Entrepreneurship Education $\left(X_{1}\right)$ to Entrepreneurial Motivation $(Z)$}

Based on the analysis results, it is discovered that entrepreneurial motivation variable $(Z)$ is explained by entrepreneurship education $\left(X_{1}\right)$ by 11.580 with the probability magnitude (Sig.) for entrepreneurship education of $0.000>0.05$ and the value of $t_{\text {count }} \geq t_{\text {table }}(11.580<1.65573)$. This means that entrepreneurship education variable $\left(X_{1}\right)$ affects positively and significantly to entrepreneurial motivation $(Z)$. Therefore, $\mathrm{H}_{\mathrm{a}}$ is accepted (significant), that implies entrepreneurship education variable $\left(X_{1}\right)$ makes a significant effect on entrepreneurial motivation $(Z)$. It can be interpreted that entrepreneurship education variable affects entrepreneurial motivation.

\section{Effects of Entrepreneurial Personality $\left(X_{2}\right)$ to Entrepreneurial Motivation $(Z)$}

From the analysis results, it is discovered that entrepreneurial motivation $(Z)$ is explained by gender variable by 1.039 with the probability magnitude (Sig.) for gender of $0.301<0.05$ and the value of $t_{\text {count }} \geq t_{\text {table }}(1.039>1.65573)$. This means that gender variable $\left(X_{2}\right)$ affects positively and significantly to entrepreneurial motivation $(Z)$. Therefore, $H_{a}$ is accepted (significant), that implies gender variable $\left(X_{2}\right)$ makes a significant effect on entrepreneurial motivation $(Z)$. It can be interpreted that gender variable affects entrepreneurial motivation.

\section{Effects of Interest in Entrepreneurship (Y) to Entrepreneurial Motivation (Z)}

Based on the analysis results, it is discovered that entrepreneurial motivation $(Z)$ is explained by interest in entrepreneurship by 8.172 with the probability magnitude (Sig.) for interest in entrepreneurship of $0.000>0.05$ and the value of $t_{\text {count }}$ $\geq t_{\text {table }}(8.172<1.65573)$. This means that interest in entrepreneurship (Y) affects positively and significantly to entrepreneurial motivation $(Z)$. Therefore, $H_{a}$ is accepted (significant), that implies interest in entrepreneurship (Y) makes a significant effect on entrepreneurial motivation (Z). It can be interpreted that interest in entrepreneurship variable affects entrepreneurial motivation.

\section{Sobel Test}

Sobel Test that is derived from the results described above generates indirect effects between exogenous and endogenous variables through SPSS 16.0 calculation. It is obtained that there is a direct effect of entrepreneurship education $\left(\mathrm{X}_{1}\right)$ on interest in entrepreneurship $(\mathrm{Y})$ by $0.522 \times 8.172=4.2657$, and a direct impact on the gender variable $\left(\mathrm{X}_{2}\right)$ to interest in entrepreneurship $(\mathrm{Y})$ by $0.234 \times 8.172=1.9122$. The path 
coefficient of identified variable affecting the value of $Z\left(E_{2}\right)$ is $\sqrt{1}-0,844=0.394$, and the path coefficient of unidentified variable affecting the value of $Y\left(E_{1}\right)$ is $\sqrt{1}-0,486=$ 0,716 . The mind map of interpretation of path analysis results that has been processed by the researcher is shown below.

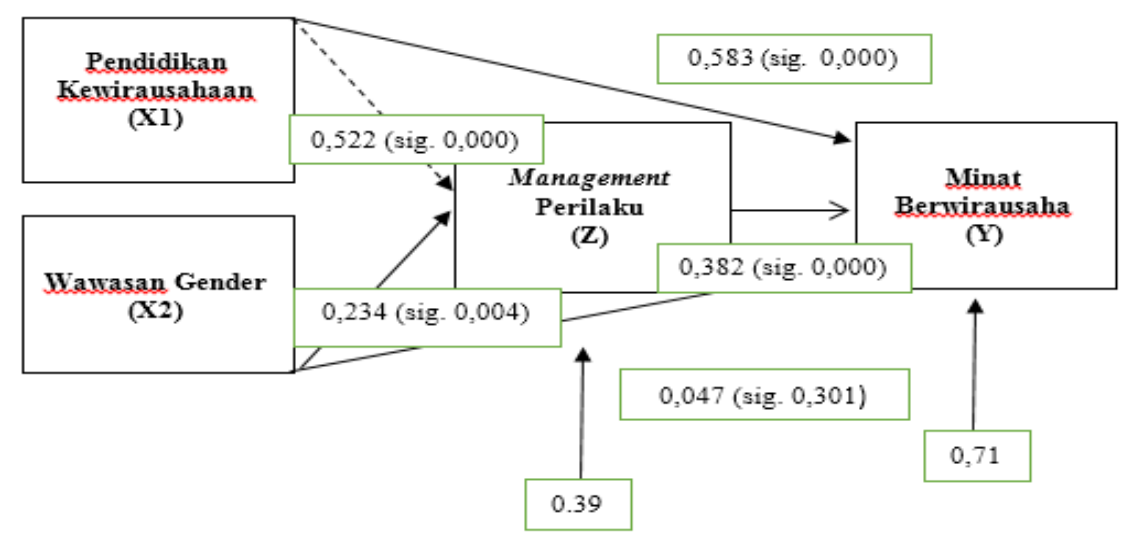

Figure 2. Interpretation of Path Analysis Result

\section{Effects on Entrepreneur Education to Entrepreneurial Motivation}

The results of hypothesis testing indicate that entrepreneurship education has a positive and significant effect on entrepreneurial motivation. These results indicate that the higher entrepreneurship education from ITB ASIA Malang is consistent to the higher entrepreneurial motivatio. The findings of this study are in accordance with the opinion of Hutagalung, et al. (2017) that stated entrepreneurship education can be interpreted as psychological as well as entrepreneurial spirit training through educational institutions. Students' entrepreneurial motivation could advance if they always follow entrepreneurship learning and entrepreneurship debriefing, theoretically and practically. Corresponding to the research done by Mahendra, et al (2017), entrepreneurship education affects positively and significantly to entrepreneurial motivation. Entrepreneurship education is an entrepreneurial spirit and mental effort done through educational institute. Entrepreneurship education is aimed to motivate and to shape the mental attitude of entrepreneurs.

\section{Effects of Gender to Entrepreneurial Motivation}

The results of hypothesis testing indicate that gender has a significant effect on entrepreneurial motivation. These results indicate that gender takes an important role in entrepreneurial motivation. The results of this study are in accordance with the opinion of Aidha (2016) that stated potential business opportunities can be seen from both women or men who take advantage of building an business with prospective opportunities. This identification of the role of motivation in spurring the success of entrepreneurial variables generally shows that the entrepreneurial ethos can be 
stimulated. Women and men can have different talents, and it is shown from the way they motivate themselves. Corresponding to the research done by Mantik (2020), gender affects positively and significantly to entrepreneurial motivation. Entrepreneurial motivation offers a real illustration that motivation cannot be separated from push-and-pull factors that continue entrepreneurship. Based on the results of calculation and previous studies, it can be concluded that gender takes a role on affecting entrepreneurial motivation of students of ITB ASIA Malang.

\section{Effects of Entrepreneurship Education to Interest in Entrepreneurship}

The results of hypothesis testing indicate that entrepreneurship education has a significant effect on interest in entrepreneurship. These results indicate that entrepreneurship education helps develop students' interest in entrepreneurship. The results of this study are in accordance with the statement by Alma (2009) that the foundation for the emergence of interest in entrepreneurship is education, family environment, personal values, age, and working experiences. Entrepreneurship education can be obtained from many entrepreneurs' expertise and skills through entrepreneurship training. The meant entrepreneurship education is a learning process to change students' behavior and mindset on their options in entrepreneurship career. Therefore, students who have taken Entrepreneurship course will have true values and entrepreneurial characteristics, thus the interest in entrepreneurship is enhanced and their love for entrepreneurship world grows. The result of the hypothesis testing showed that entrepreneurship education affects significantly to interest in entrepreneur (Lestari and Wijaya, 2012). Entrepreneurship education affects significantly to the interest of Economics Education students (Putri, 2017).

\section{Effects of Gender to Interest in Entrepreneurship}

The results of hypothesis testing indicate that gender has an effect on interest in entrepreneurship. These results indicate that the direct impact on gender to interest in entrepreneurship of students of ITB ASIA Malang is accepted. Differences in the role status between men and women are shaped by society based on cultural values in a certain period of time. The results of this study are in accordance with the statement of Barlin (2011). Each individual is born with different personality, and each personality of an individual can be trained and developed. Interest in entrepreneurship of the students of ITB ASIA Malang is supported by traits that could promote their competence to build and run the business. Based on the results of calculation and previous studies, it can be concluded that gender takes a role on affecting interest in entrepreneurship of students of ITB ASIA Malang.

\section{Effects of Entrepreneurial Motivation to Interest in Entrepreneurship}

The results of hypothesis testing indicate that entrepreneurial motivation has a direct effect on the interest in entrepreneurship. These results indicate that entrepreneurial motivation has a significant and positive implication on the interest in 
entrepreneurship. The results of this study are in accordance with the opinion of Solesvik (2012). One of the factors that influence the emergence of interest in entrepreneurship is entrepreneurial motivation, that is needed to run or to own a business by taking advantage of existing business opportunities, and to build new businesses with an innovative approach.

The hypothesis that stated if there is a direct effect of entrepreneurial motivation to interest in entrepreneurship of students of ITB ASIA Malang is accepted. This meant that self-efficacy significantly gives positive implication to the interest in entrepreneurship. This finding is corresponding to the study done by Aidha (2016). Based on the previous studies, it can be concluded that entrepreneurial motivation takes a role on affecting interest in entrepreneurship of students of ITB ASIA Malang. Self-efficacy will develop and grow through competence and experience done by every individual who can grow their self-confidence to reach the desired target. Likewise, interest in entrepreneurship of students of ITB ASIA Malang also needs high self-efficacy, because being a successful entrepreneur needs strong spirit and mental to face entrepreneurial threats.

\section{Entrepreneurial Motivation Moderates Direct Relation between Entrepreneurship Education and Interest in Entrepreneurship}

The results of hypothesis testing indicate that entrepreneurship education through entrepreneurial motivation has a significant effect on interest in entrepreneurship. These results indicate that entrepreneurship education is needed to achieve entrepreneurial motivation with an interest in entrepreneurship. The results of this study are in accordance with the opinion of Ekpoh and Edet (2011) that stated entrepreneurship education is needed by prospective entrepreneurs in their business. From the indicators existing in the entrepreneurial education variable, it strengthens the opinion that the obtained entrepreneurship education has an influence on the interest in entrepreneurship of the students of ITB ASIA Malang. This is consistent with the objectives of the entrepreneurship education, that is to provide provisions and to train students' entrepreneurial spirit.

The calculation showed a value of direct effect by 0.583 and 4.848 , meaning that entrepreneurship education $\left(X_{1}\right)$ through entrepreneurial motivation $(Z)$ directly affects interest in entrepreneurship (Y). A research done by Farida and Nurkhin (2016) found that entrepreneurship education affects interest in entrepreneurship. This finding is corresponding to the study done by Lestari and Wijaya (2012) that showed entrepreneurship education affects interest in entrepreneurship.

\section{Entrepreneurial Motivation Moderates Direct Relation between Gender and Interest in Entrepreneurship}

The results of hypothesis testing indicate that gender, through entrepreneurial motivation, has a significant effect on interest in entrepreneurship. These results 
indicate that gender affects entrepreneurial motivation followed by higher interest in entrepreneurship by the students of the Faculty of Economics and Business of ITB ASIA Malang. The results of this study are in accordance with the opinion of Paramitasari \& Muhyadi (2016) who conducted research with the variables of entrepreneurial motivation and entrepreneurial knowledge on entrepreneurial interest. This means that it is needed to increase the motivation level of a student in carrying out entrepreneurial activities, so that it will increase their level of interest in entrepreneurship.

The calculation showed a value of direct effect by 0.234 and 0.251 , meaning that gender $\left(X_{2}\right)$ through entrepreneurial motivation $(Z)$ directly and significantly affects interest in entrepreneurship (Y). Paramitasari and Muhyadi (2016) conducted a research using entrepreneurial motivation and entrepreneurship knowledge variables to interest in entrepreneurship. The data were analysed using simple linear analysis and multiple linear analysis techniques. It can be interpreted that independent variables affect positively and significantly to dependent variables.

\section{Conclusion}

Based on the findings, conclusion is formulated as follow.

- There is a direct effect of entrepreneurship education on interest in entrepreneurship.

- There is a direct impact on gender to interest.

- There is a direct effect of entrepreneurship education on entrepreneurial motivation.

- There is a direct impact on gender to entrepreneurial motivation

- There is a direct effect of interest in entrepreneurship on entrepreneurial motivation.

- There is a direct effect of entrepreneurship education on entrepreneurial motivation with a path coefficient of E2 and E1.

- There is a direct impact on gender to entrepreneurial motivation with a path coefficient of E2 and E1.

It is recommended for future researchers to investigate and to develop this research topic with other related variables such as family environment, entrepreneurial characteristic, entrepreneurship knowledge, and facilities of business centre to get in-depth results. Based on strength indicator in this research's findings, for prospective students of Business and Management Education, there is a need of self-improvement through standing up after failure and evaluate the causes of the said failure, and getting even more passionate seeing others' succeed.

\section{References}

Aidha, Z. (2016). Pengaruh Motivasi Terhadap Minat Berwirausaha Mahasiswa Fakultas Kesehatan Masyarakat Universitas Islam Negeri Sumatera Utara. 
Journal of Knowledge Management, 2(2), 1-18. https:// doi.org/10.1016/j.cya.2015.11. 011

Ali, S., Haider, Z., Munir, F., Khan, H., \& Ahmed, A. (2013). Factors contributing to the students academic performance: A case study of Islamia University SubCampus. American journal of educational research, 1(8), 283-289.

Alma, Buchari. (2013). Kewirausahaan. Bandung: Alfabeta.

Bappenas. Tujuan Pembangunan Berkelanjutan. Kementerian PPN / Bappenas (2020).

Barlin, B. (2011) 'Pengaruh Latar Belakang Pendidikan Dan Gender Terhadap Minat Berwirausaha Mahasiswa Universitas Andalas', Document Ripository Universitas Andalas. Available at: http://repo.unand.ac.id/id/eprint/2090.

Baum, J. R., Frese, M., Baron, R. A., \& Katz, J. A. (2007). Entrepreneurship as an area of psychology study: An introduction. The psychology of entrepreneurship, 1, 18

Dayakishi, Tri., Salis Yuniardi. (2008). Psikologi Lintas Budaya (Edisi Revisi). Malang : UMM Press

Ekpoh, U. I., \& Edet, A. O. (2011). Entrepreneurship education and career intentions of tertiary education students in Akwa Ibom and Cross River States, Nigeria. International Education Studies, 4(1), 172-178.

Farhangmehr, M., Gonçalves, P., \& Sarmento, M. (2016). Predicting entrepreneurial motivation among university students: The role of entrepreneurship education. Education+ Training.

Ghozali, Imam. 2011. "Aplikasi Analisis Multivariate Dengan Program SPSS". Semarang: Badan Penerbit Universitas Diponegoro.

Guzman, J., \& Kacperczyk, A. O. (2019). Gender gap in entrepreneurship. Research Policy, 48(7), 1666-1680.

Hutagalung, B., Dalimunthe, D. M. J., Pambudi, R., Hutagalung, A. Q., \& Muda, I. (n.d.). The Effect of Enterpreneurship Education and Family Environment Towards Students' Entrepreneurial Motivation. 19.

Indarti, N. dan Rokhima R., (2008). “Intensi Kewirausahaan Mahasiswa: Studi Perbandingan Antara Indonesia, Jepang dan Norwegia". Jurnal Ekonomika dan Bisnis Indonesia, 23 (4).

Kurnianti, Edy Dwi. (2015). Kewirausahaan Industri. Yogyakarta: Depublish.

Lestari, R. B., \& Wijaya, T. (2012). Pengaruh pendidikan kewirausahaan terhadap minat berwirausaha mahasiswa di STIE MDP, STMIK MDP, dan STIE MUSI. In Forum Bisnis Dan Kewirausahaan Jurnal Ilmiah STIE MDP (Vol. 1, No. 2, pp. 112-119). STIE MDP.

Liñán, F., Rodríguez-Cohard, J. C., \& Rueda-Cantuche, J. M. (2011). Factors affecting entrepreneurial intention levels: a role for education. International entrepreneurship and management Journal, 7(2), 195-218.

Mahendra, A. M., Djatmika, E. T., \& Hermawan, A. (2017). The Effect of Entrepreneurship Education on Entrepreneurial Intention Mediated by Motivation and Attitude among Management Students, State University of Malang, Indonesia. International Education Studies, 10(9), 61. https:// doi.org/10.5539/ies.v10n9p61 
Mantik, J. C., Tewal, B., \& Dotulong, L. O. H. (2020). Analisis Faktor-Faktor Yang Mempengaruhi Motivasi Berwirausaha Pada Pengusaha Kecil Di Kota Manado. 11.

Nurmaliza, N., Caska, C., \& Indrawati, H. (2018). Analysis of factors affecting entrepreneurial interest of vocational high school students in Pekanbaru. Journal of Educational Sciences, 2(2), 42-51.

Olugbola, S. A. (2017). Exploring entrepreneurial readiness of youth and startup success components: Entrepreneurship training as a moderator. Journal of Innovation \& Knowledge, 2(3), 155-171.

Patriana, P. (2007). Hubungan antara kemandirian dengan motivasi bekerja sebagai pengajar les privat pada mahasiswa di Semarang (Doctoral dissertation, Universitas Diponegoro).

Paramitasari dan Muhyadi. 2016. Pengaruh Motivasi Berwirausaha dan Pengetahuan Kewirausahaan Terhadap Minat Berwirausaha Siswa Kelas XI Kompetensi Keahlian Administrasi Perkantoran SMKN 1 Bantul. Jurnal Pendidikan Administrasi Perkantoran. Volume 05, No. 03.

Putri, N. L. W. W. (2017). Pengaruh Pendidikan Kewirausahaan Terhadap Minat Mahasiswa Untuk Berwirausaha Pada Mahasiswa Pendidikan Ekonomi Universitas Pendidikan Ganesha. Jurnal Pendidikan Ekonomi Undiksha, 9(1), 137. https://doi.org/10.23887/jjpe.v9i1.19998

Solesvik, M. Z. (2013). Entrepreneurial motivations and intentions: Investigating the role of education major. Education + Training, 55(3), 253-271. https:/ / doi.org/10.1108/00400911311309314

Souitaris, V., Zerbinati, S., \& Al-Laham, A. (2007). Do entrepreneurship programmes raise entrepreneurial intention of science and engineering students? The effect of learning, inspiration and resources. Journal of Business venturing, 22(4), 566591.

Wardhani, W. D. L., Puspitasari, N., Lestari, E. D., \& Sulistianingsih, A. (2019). Boneka Gender: Implementasi Metode Proyek Pendidikan Gender Pada Calon Guru Paud. Paud Lectura: Jurnal Pendidikan Anak Usia Dini, 2(02), 86-101.

Wulandari, A., Hermawan, A., \& Mukhlis, I. (2021). Exploring Determinants of Entrepreneurial Readiness on Sukses Berkah Community's Member. Journal of Business and Management Review, 2(4), 303-317. https:/ / doi.org/10.47153/jbmr24.1332021 